\title{
21. VOLCANIC BRECCIA FROM DSDP SITE 357: IMPLICATIONS FOR THE COMPOSITION AND ORIGIN OF THE RIO GRANDE RISE
}

\author{
R.V. Fodor, Department of Geology and Institute of Meteoritics, \\ University of New Mexico, Albuquerque, New Mexico \\ and \\ Jörn Thiede, School of Oceanography, Oregon State University, Corvallis, Oregon
}

\begin{abstract}
A volcanic breccia ( $4 \mathrm{~m}$ thick) was recovered from middle Eocene sediments at Site 357, Leg 39, Rio Grande Rise, South Atlantic Ocean. The breccia is composed largely of basaltic fragments $(\sim 0.5$ to $3 \mathrm{~cm}$ ) and Eocene shallow-water fossils in a clayey matrix. Texture suggests a hyaloclastic origin, and sorting of components indicates slump deposition. Although most basaltic material is altered (smectities, carbonate), fresh clinopyroxenes (Fso-16 Wo45-51) remain and have compositions similar to clinopyroxene in highly alkalic basaltic rocks, thus identifying the parentage of the altered basalt fragments. The affinity of both hyaloclastites and alkalic oceanic basaltic-material to seamounts and islands suggests that the breccia formed by eruption from an alkali-rich seamount or volcano, probably during Eocene time. Shallow-water fauna and sorting indicate that it subsequently slumped to a pelagic environment. This breccia provides the first quantitative data for the composition of basement material of the Rio Grande Rise, whereby it is composed, at least in part, of volcanic material not typically oceanic crust (tholeiitic).
\end{abstract}

\section{INTRODUCTION}

The Rio Grande Rise is an aseismic structural high towering more than $3 \mathrm{~km}$ above the South Atlantic Ocean floor. Uppermost peaks of this largely sediment-covered feature reach water depths of 600 to 700 meters (Dietrich and Ulrich, 1968), and its essentially east-west orientation influenced paleocirculation and paleoenvironments throughout most of the history of the South Atlantic Ocean. The origin of the Rio Grande Rise during rifting of the South Atlantic Ocean is still controversial, largely because of the lack of knowledge about the composition of its crystalline basement. Geophysical data on the western part of the rise suggested continental crust (Leyden et al., 1971), whereas samples dredged by Lamont-Doherty Geological Observatory in 1973 included volcanic material, some of which is trachyandesite (Fodor, unpublished data). In any case, sediment and stratigraphic data indicate that it was a large island, 2 to $3 \mathrm{~km}$ above sea level during Santonian to Campanian time ( 85 to 75 m.y. ago), that underwent subsidence (Thiede, in press). To date, the rise has been explained as related to a hotspot (Dietz and Holden, 1970; Morgan, 1971), or as related to major fracture zones associated with rifting (Le Pichon and Hayes, 1971).

Attempts have been made to core completely through the sediment layer during DSDP Legs 3 and 39 (Maxwell et al, 1970; Perch-Nielsen et al., this volume), but none were successful. Drilling at Site 357 during Leg 39 (Figure 1), however, did yield igneous material in 4 meters of breccia composed mainly of basaltic fragments, and located between middle-Eocene calcareous pelagic sediments. Although this breccia is not from the basement of the rise, it marks the first in situ recovery of volcanic material from the rise that can provide information about the type of volcanic material forming part of the Rio Grande Rise (presumably its basement) during Eocene time, and the origin of the rise. This report presents the mineralogy, chemistry, and petrology of the basaltic components of the Leg 39 volcanic breccia and its geologic implications on the composition and history of the Rio Grande Rise.

\section{ANALYTICAL PROCEDURES}

Mineral compositions were determined by an ARLEMX electron microprobe operated at $15 \mathrm{keV}$ and 0.015 to $0.020 \mu \mathrm{A}$ sample current. $\mathrm{H}_{2} \mathrm{O}$ content of the breccia ( $1 \mathrm{~g}$ sample) was determined by ignition loss, where the amount of $\mathrm{Fe}$ oxidation was taken into account by $\mathrm{K}_{2} \mathrm{Cr}_{2} \mathrm{O}_{7}$ titration of $\mathrm{Fe}^{+2}$ in both ignited and unignited samples. $\mathrm{CO}_{2}$ content was determined by acid-base titration ( $0.5 \mathrm{~g}$ sample).

\section{GENERAL DESCRIPTION}

The stratigraphic position of the Rio Grande rise breccia is illustrated in Figure 2. The breccia is well indurated, dense and composed of light-colored shell 


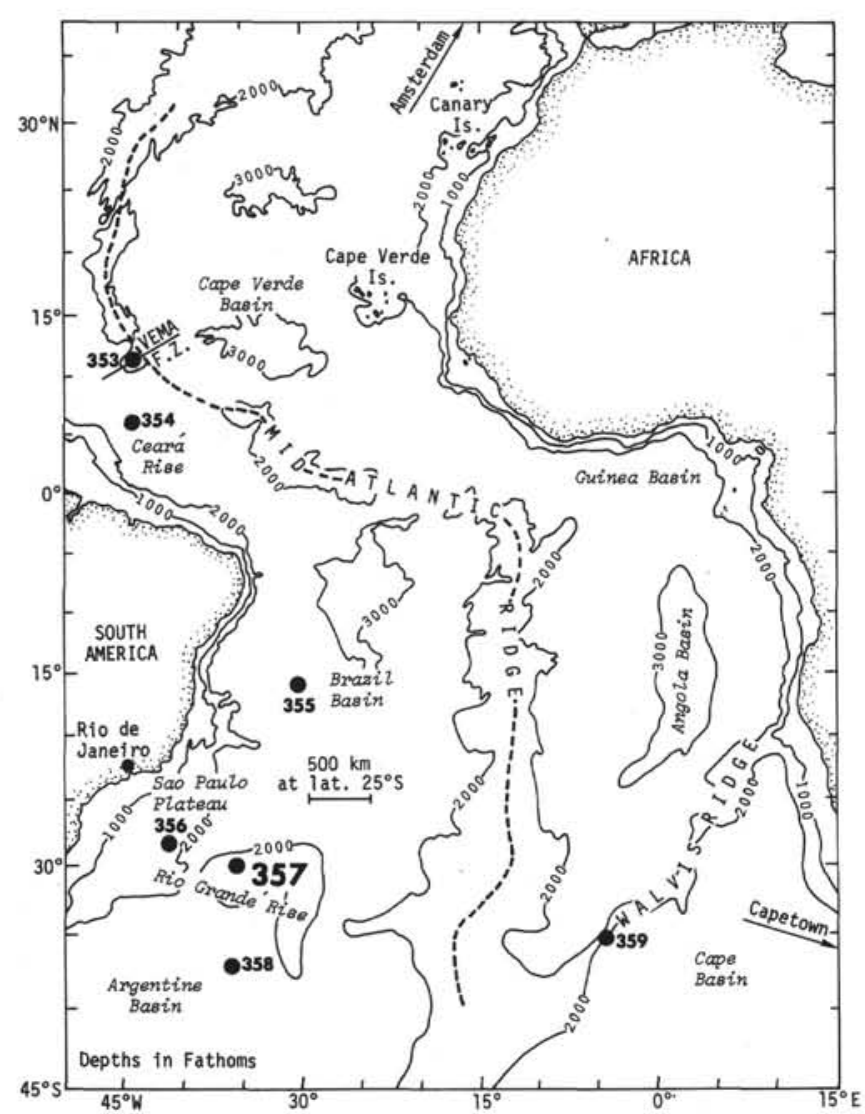

Figure 1. Map of the South Atlantic Ocean showing the locations of Site 357 and other sites drilled during Leg 39B, DSDP.

and limestone fragments, dark colored basaltic fragments, and individual black pyroxene grains, in a clayey matrix (Figure 3). Also present are calcium carbonate grains, both in the breccia matrix and in basaltic fragments, and feldspar grains in the matrix. Whereas most of the basaltic fragments are gray or greenish-gray in color (apparently altered), a few appear black and glassy. The combination of variegated fragments and clayey matrix give the breccia an overall greenish-gray color; its general appearance is similar to that of hyaloclastites described and illustrated by Bonatti (1967). Clasts are somewhat sorted and indicative of graded bedding. Throughout the 4-meter core, fragment sizes average 0.5 to $1 \mathrm{~mm}$ in the upper portion, and are as large as $3 \mathrm{~cm}$ in the lower portion.

A modal analysis of one thin section showed that the breccia is composed of about $57 \%$ (volume) fragments and $43 \%$ matrix material. The fossiliferous fragments include planktonic and benthic foraminifers, bivalve and gastropod shell fragments, bryozoans, and red algae, all compatible with a shallow-water environment. Of concern here, however, are the basaltic fragments, which make up the greatest percentage of clasts. The size of the basaltic fragments ranges from about $0.1 \mathrm{~mm}$ to over $1 \mathrm{~cm}$ and they are subangular in form (Figures 4 and 5).

The fragments contain phenocrysts and microlites in matrices that vary in color under plane-polarized light from clear, to pale yellow, to light green, to gray and nearly opaque. Under crossed nicols, all fragments are essentially isotropic. The phenocrysts (up to $1 \mathrm{~mm}$ in size) consist mainly of clinopyroxene and a secondarily formed carbonate phase which appears, in some cases, to have replaced primary phenocrysts. Crystal outlines of some carbonate grains suggest that they may have replaced olivine in the basaltic fragments (Figure 5). Rare plagioclase, oxides, and sanidine were also observed; the sanidine is present only as individual grains in the matrix. Each fragment contains vesicles (up to $0.1 \mathrm{~mm}$ ), many of which are filled with microcrystalline material, possibly zeolites. Microlites in the fragment matrices are mainly clinopyroxene and are sometimes aligned parallel, suggesting flowage before fragmentation. The matrix material for the breccia is light brown to gray in color under plane light, and is birefringent and brownish under crossed nicols.

A partial wet-chemical analyses of the breccia yielded the following: $\mathrm{H}_{2} \mathrm{O}-4.06$ wt \%; $\mathrm{H}_{2} \mathrm{O}^{+} 10.60 \%$; $\mathrm{CO}_{2}$ $5.61 \% ; \mathrm{FeO} 2.53 \%$. The total volatile content of about $20 \mathrm{wt} \%$ indicates extensive alteration and replacement of primary phases by clay minerals and carbonate
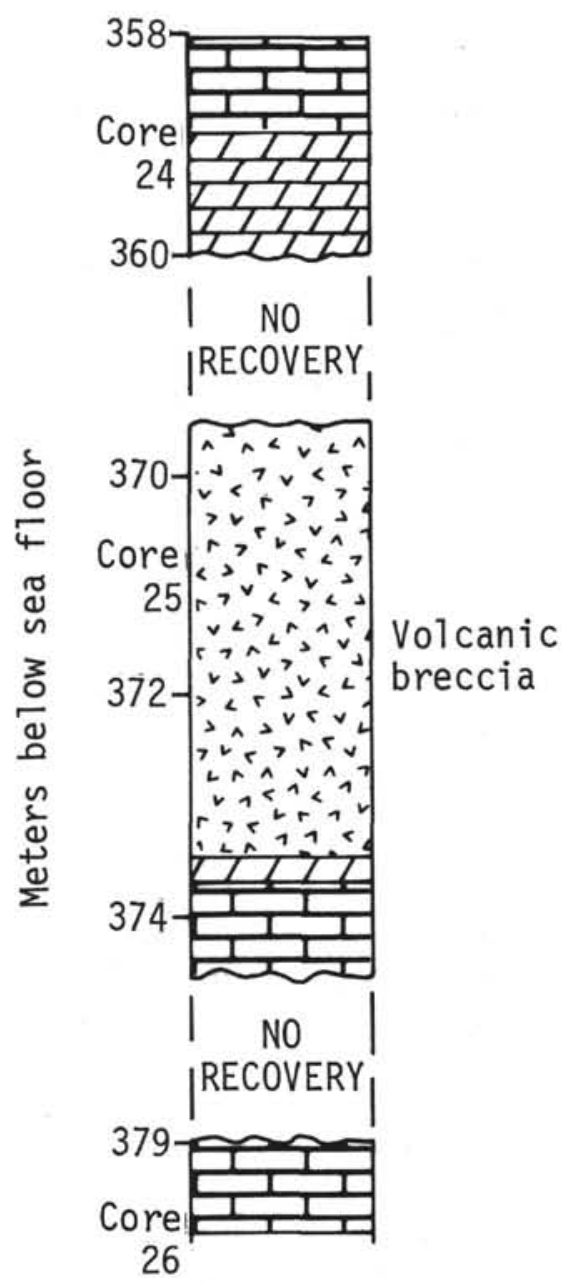

Figure 2. Stratigraphy in the region of the volcanic breccia, Site 357, Rio Grande rise. Over- and underlying sediments are Eocene in age. 


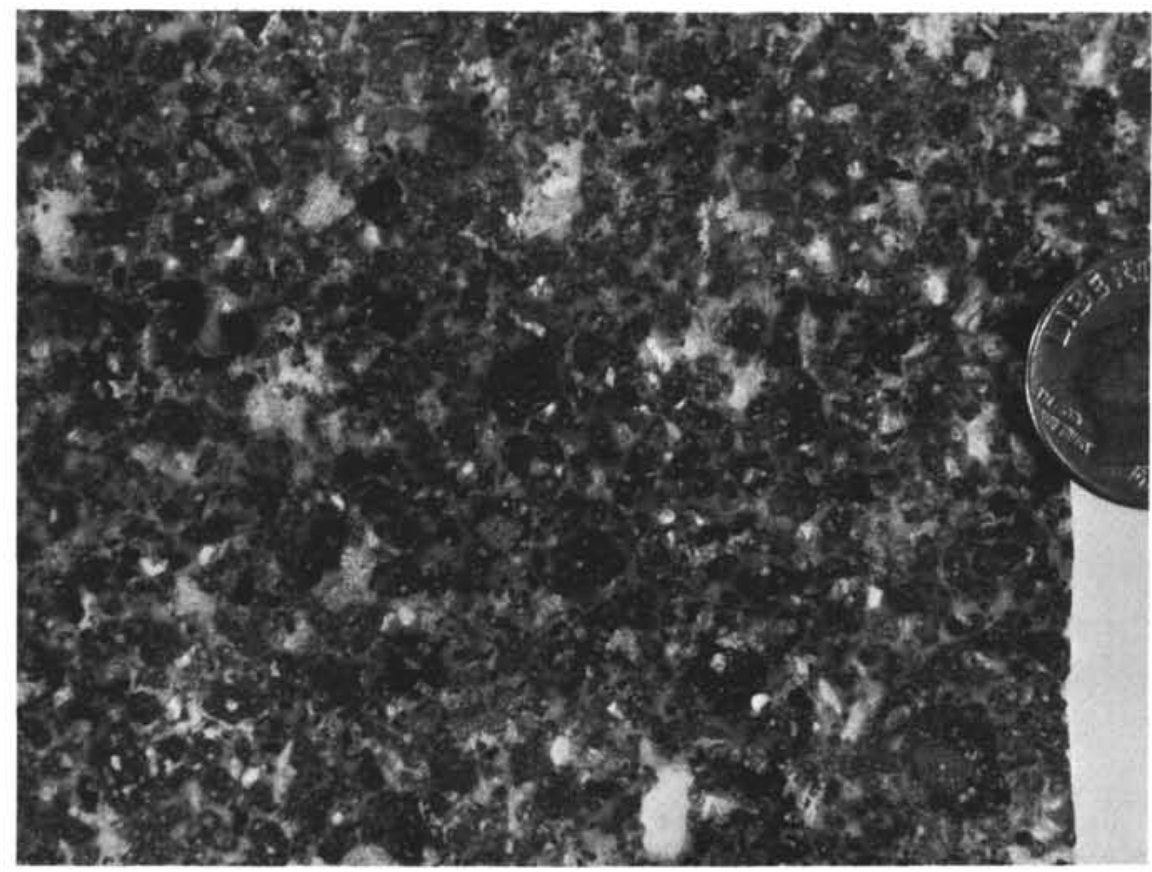

Figure 3. The overall appearance of the Rio Grande rise breccia showing mainly dark-colored lithic fragments in an intermediate-colored clayey matrix. The coin provides scale.

minerals; some $\mathrm{H}_{2} \mathrm{O}$ content, however, is probably from admixed pelagic sediments. The low $\mathrm{FeO}$ content indicates that most $\mathrm{Fe}$ is $\mathrm{Fe}^{+3}$.

\section{MINERAL ANALYSES}

Average compositions for 16 unaltered clinopyroxene phenocrysts and microphenocrysts within basaltic fragments and as individual grains in the breccia matrix ( 9 of which are in the same basaltic fragment, $5 \mathrm{~mm}$ in size) were determined by electron microprobe (Table 1). All of the grains have high $\mathrm{CaO}$ content, where wollastonite (Wo) endmembers range about 46 to 50 mole \% and are rich in $\mathrm{SiO}_{2}$ and $\mathrm{Al}_{2} \mathrm{O}_{3}$. Within-grain compositional variation is mainly $\mathrm{Si}-\mathrm{Al}$ (Ti) substitution, and the variation in $\mathrm{FeO}, \mathrm{MgO}$, and $\mathrm{CaO}$ contents is small. Also, intergrain average values for $\mathrm{SiO}_{2}$ and $\mathrm{Al}_{2} \mathrm{O}_{3}$ range widely (Table 1)-even among the nine grains analyzed from one basaltic fragment. There is also intergrain variation of $\mathrm{FeO}$ contents that range from 5.6 to 13.7 mole \% ferrosilite (Fs). All clinopyroxene grains have considerable $\mathrm{Na}_{2} \mathrm{O}$ contents, but $\mathrm{Cr}_{2} \mathrm{O}_{3}$ contents range from less than 0.01 wt \% up to $0.87 \%$; the higher $\mathrm{Cr}_{2} \mathrm{O}_{3}$ values are associated with higher $\mathrm{MgO}$ contents.

The relatively high $\mathrm{CaO}, \mathrm{Al}_{2} \mathrm{O}_{3}$, and low $\mathrm{SiO}_{2}$ contents of the pyroxenes are compatible with those in pyroxenes in nephelinic (highly alkalic) basalt and not with those in tholeiitic (ocean ridge) basalt; tholeiites have pyroxenes lower in $\mathrm{CaO}$ (generally $<\mathrm{W}_{040}$ ) and $\mathrm{Al}_{2} \mathrm{O}_{3}$, and higher in $\mathrm{SiO}_{2}$ (commonly $>50$ wt \%) (Fodor et al., 1975). Also, extensive $\mathrm{SiO}_{2}$ and $\mathrm{Al}_{2} \mathrm{O}_{3}$ substitution attended by relatively stable within-grain $\mathrm{Fe} / \mathrm{Mg}$ and $\mathrm{Fe} / \mathrm{Ca}$ ratios occur in clinopyroxenes of nephelinic basalt (Fodor et al., 1975). Average compositions of pyroxenes in some Hawaiian nephelinic basalt are very similar to those of the clinopyroxenes in the basaltic fragments of the Rio Grande Rise breccia (Table 1).

An analysis of one sanidine grain yielded $\mathrm{SiO}_{2} 65.1$ wt \%; $\mathrm{Al}_{2} \mathrm{O}_{3}$ 19.4\%; $\mathrm{FeO} 0.32 \% ; \mathrm{MgO} 0.36 \%$; $\mathrm{CaO}$ $0.47 \% ; \mathrm{Na}_{2} \mathrm{O} 1.8 \% ; \mathrm{K}_{2} \mathrm{O} 13.1 \%$; feldspar end members are anorthite $2.4 \%$; albite $16.8 \%$, and orthoclase $80.8 \%$. A semiquantitative analysis of several carbonate grains showed $\mathrm{CaO} 31.4$ wt \%; $\mathrm{MgO} 15.8 \%$; and $\mathrm{FeO} 4.1 \%$, corresponding to dolomite in composition.

One basaltic fragment $(5 \mathrm{~mm})$ that appeared glassy in hand sample was separated from the breccia for analysis of its matrix (this is the same fragment in which nine pyroxene grains were analyzed). Although it did not polish well, suggesting that it was no longer glass, a microprobe analysis could still be made by restricting the electron beam to the "best" polished areas. The composition (Table 2) resembles a high- $\mathrm{Na}$, low-K and -Al smectite, partly resembling the iron-rich saponite described by Banks (1972), and in part resembling some of the high- $\mathrm{Ti}$ and low- $\mathrm{Mg}$ smectite described by Melson and Thompson (1973). Just as the smectite described by these authors, the smectite here is a replacement of original basaltic glass by alteration. The glassy appearance of the examined breccia fragment indicates that it is probably palagonite; the low summation (Table 2) indicates the presence of about 11 wt $\% \mathrm{H}_{2} \mathrm{O}$.

Attempts to analyze matrices of other, more altered, fragments proved difficult because their softness precluded obtaining a good polish. Semiquantitative analyses, however, showed consistently low $\mathrm{SiO}_{2}$ (39 to 46 wt \%), low $\mathrm{Al}_{2} \mathrm{O}_{3}$ (8 to 11 wt \%), and $\mathrm{FeO}$ and $\mathrm{Na}_{2} \mathrm{O}$ contents lower than in the analysis presented in Table 2 (6 to $12 \%$, and $0.50 \%$ to $1.0 \%$, respectively). A semi- 


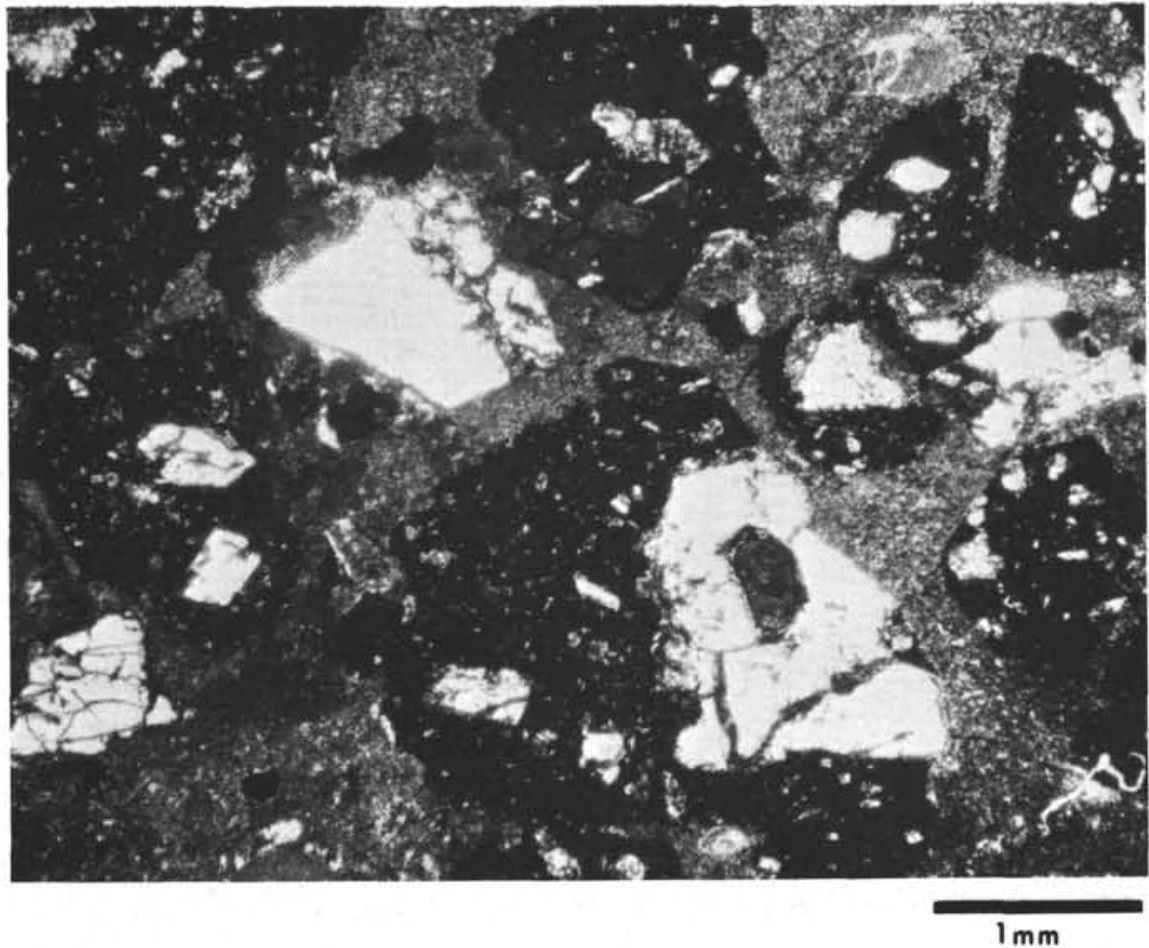

Figure 4. Subangular basaltic-fragments (dark areas) with phenocrysts of clinopyroxene and carbonate (light areas), and microlites and secondary minerals in the groundmass; the groundmasses are altered to clay minerals (see Table 2). Crossed nicols; scale bar equals $1 \mathrm{~mm}$.

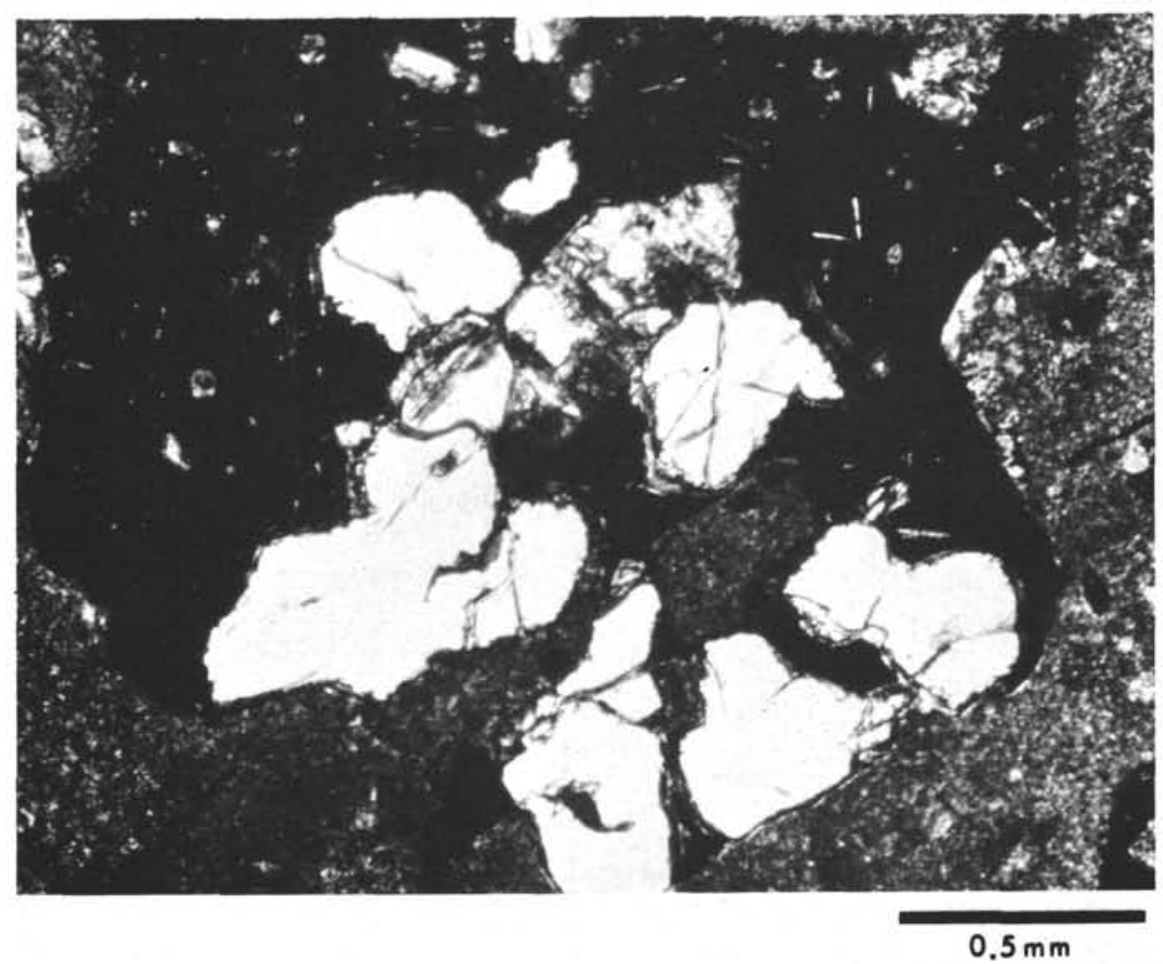

Figure 5. Closeup of a basaltic fragment (altered to clay) containing clinopyroxene grains (light-colored) and a dolomitic crystal (center) having crystal outline (pyramidal) resembling what may have originally been a euhedral olivine crystal. Crossed nichols; scale bar equals $0.5 \mathrm{~mm}$. 
TABLE 1

Average Compositions (wt\%) of Clinopyroxene in the Volcanic Breccia

from the Rio Grande Rise, South Atlantic Ocean (Columns 1-16)

Compared to Clinopyroxenes in Two Hawaiian Nephelinic Basalts (C148, C139)

\begin{tabular}{|c|c|c|c|c|c|c|c|c|c|}
\hline & 1 & 2 & 3 & 4 & 5 & 6 & 7 & 8 & 9 \\
\hline $\mathrm{SiO}_{2}$ & 49.8 & 50.3 & 48.7 & 50.8 & 46.6 & 46.8 & 48.6 & 49.8 & 46.0 \\
\hline $\mathrm{TiO}_{2}$ & 1.8 & 1.7 & 2.5 & 2.0 & 3.6 & 2.5 & 2.8 & 1.7 & 3.5 \\
\hline $\mathrm{Al}_{2} \mathrm{O}_{3}$ & 6.3 & 4.3 & 5.9 & 3.8 & 7.1 & 7.0 & 5.8 & 7.0 & 7.2 \\
\hline $\mathrm{Cr}_{2} \mathrm{O}_{3}$ & 0.36 & 0.16 & 0.16 & 0.11 & 0.36 & 0.25 & 0.37 & 0.02 & 0.21 \\
\hline $\mathrm{FeO}$ & 4.2 & 4.6 & 4.8 & 5.0 & 5.1 & 5.2 & 5.4 & 5.5 & 7.0 \\
\hline $\mathrm{MnO}$ & 0.07 & 0.06 & 0.09 & 0.12 & 0.10 & 0.12 & 0.09 & 0.12 & 0.12 \\
\hline $\mathrm{MgO}$ & 15.0 & 15.6 & 14.3 & 15.0 & 14.2 & 14.3 & 14.0 & 14.3 & 12.3 \\
\hline $\mathrm{CaO}$ & 2.6 & 22.1 & 23.2 & 23.2 & 23.3 & 23.1 & 23.3 & 21.6 & 23.2 \\
\hline $\mathrm{Na}_{2} \mathrm{O}$ & 0.50 & 0.31 & 0.44 & 0.49 & 0.42 & 0.49 & 0.27 & 0.87 & 0.33 \\
\hline Total & 100.63 & 99.13 & 100.09 & 100.52 & 100.78 & 99.76 & 100.63 & 100.91 & 100.36 \\
\hline \multicolumn{10}{|c|}{ Molecular end members } \\
\hline Fs & 7.0 & 7.6 & 8.0 & 8.1 & 8.5 & 8.6 & 9.0 & 9.4 & 11.8 \\
\hline En & 44.6 & 45.8 & 42.5 & 43.5 & 42.0 & 42.3 & 41.4 & 43.4 & 38.3 \\
\hline \multirow[t]{2}{*}{ Wo } & 48.4 & 46.6 & 49.5 & 48.4 & 49.5 & 49.1 & 49.6 & 47.2 & 49.9 \\
\hline & 10 & 11 & 12 & 13 & 14 & 15 & 16 & $\mathrm{C} 148^{\mathrm{a}}$ & $\mathrm{C} 139^{\mathrm{a}}$ \\
\hline $\mathrm{SiO}_{2}$ & 52.6 & 51.4 & 51.3 & 51.4 & 49.5 & 47.3 & 46.0 & 46.5 & 43.2 \\
\hline $\mathrm{TiO}_{2}$ & 0.90 & 0.96 & 1.0 & 1.2 & 1.4 & 2.0 & 2.5 & 2.7 & 4.7 \\
\hline $\mathrm{Al}_{2} \mathrm{O}_{3}$ & 3.9 & 3.8 & 4.2 & 5.1 & 6.0 & 7.8 & 9.9 & 6.8 & 10.0 \\
\hline $\mathrm{Cr}_{2} \mathrm{O}_{3}$ & 0.87 & 0.78 & 0.25 & 0.60 & $<0.01$ & $<0.01$ & $<0.01$ & 0.18 & $<0.01$ \\
\hline $\mathrm{FeO}$ & 3.4 & 3.5 & 3.6 & 4.0 & 5.9 & 7.2 & 7.4 & 7.9 & 8.6 \\
\hline $\mathrm{MnO}$ & 0.11 & 0.09 & 0.06 & 0.10 & 0.15 & 0.12 & 0.13 & 0.12 & 0.12 \\
\hline $\mathrm{MgO}$ & 16.7 & 15.9 & 16.0 & 15.5 & 13.6 & 12.4 & 11.0 & 12.8 & 10.4 \\
\hline $\mathrm{CaO}$ & 21.6 & 22.1 & 22.3 & 21.9 & 21.8 & 21.8 & 21.2 & 22.4 & 22.1 \\
\hline $\mathrm{Na}_{2} \mathrm{O}$ & 0.61 & 0.49 & 0.46 & 0.62 & 0.83 & 0.87 & 0.91 & 0.42 & 0.57 \\
\hline Total & 100.69 & 99.02 & 99.17 & 100.42 & 99.18 & 99.49 & 99.04 & 99.52 & 99.69 \\
\hline \multicolumn{10}{|c|}{ Molecular end members } \\
\hline Fs & 5.6 & 5.8 & 5.9 & 6.7 & 10.2 & 12.6 & 13.7 & 13.3 & 15.5 \\
\hline En & 48.9 & 47.1 & 47.0 & 46.3 & 41.7 & 38.6 & 36.2 & 38.4 & 33.4 \\
\hline Wo & 45.5 & 47.1 & 47.1 & 47.0 & 48.1 & 48.8 & 50.1 & 48.3 & 51.1 \\
\hline
\end{tabular}

Note: Grains 1-9 are present within one basaltic fragment. Each analysis represents the average of 10-20 spot analyses per grain by electron microprobe.

${ }^{\mathrm{a}}$ After Fodor et al., 1975.

quantitative analysis of the clayey breccia matrix yielded a smilar composition. These low values reflect the high $\mathrm{H}_{2} \mathrm{O}$ and $\mathrm{CO}_{2}$ contents (about 20 wt \%) in the whole breccia. X-ray diffraction showed the presence of smectite (montmorillonite), plus substantial amounts of carbonate.

\section{DISCUSSION}

On the basis of texture and mineral compositions, the Rio Grand Rise breccia is composed largely of lithic fragments representing alkali-rich basaltic material that underwent hydration and alteration to clay minerals (smectites) and carbonates.

The subangular fragments which were apparently basaltic glass that was hydrated and altered to clay minerals are characteristic of hyaloclastites (Bonatti, 1967; Melson and Thompson, 1973). These are formed by explosive seafloor eruptions whereby magma introduced into seawater was cooled rapidly and shattered; the product has a brecciated structure. Thickness of the basaltic material in the breccia would have been about 2 meters if matrix and nonigneous material were eliminated, which is compatible with it representing one basaltic sea-floor eruption (some of the clayey matrix, however, may have been derived from alteration of the basaltic fragments and therefore, the original flow may have been slightly greater than the estimated $2 \mathrm{~m}$ ). The large intergrain compositional variation displayed by the pyroxenes could indicate that the basaltic fragments are from various sources and not from one flow or from one source. But similar compositional variation of pyroxenes within one rock has previously been observed in nephelinic rocks. Basanitoids from Hawaii (Fodor et al., 1975) have grains where average $\mathrm{SiO}_{2}$ and $\mathrm{Al}_{2} \mathrm{O}_{3}$ contents can range, for example, from 41.5 to $47.0 \mathrm{wt} \%$ and $7.2 \%$ to $10.9 \%$, respectively, within one rock (intragrain variation can be even greater). Hence, there is no 
TABLE 2

Average Composition (wt\%) of the Clay Mineral Matrix of One Basaltic Fragment

in the Volcanic Breccia from the Rio Grande Rise, South Atlantic Ocean

\begin{tabular}{|c|c|c|c|c|c|}
\hline $\mathrm{SiO}_{2}$ & 50.6 & \multicolumn{4}{|c|}{ Number of ions on the basis of $0=22^{2}$} \\
\hline $\mathrm{TiO}_{2}$ & 1.5 & $\mathrm{Si}$ & 7.42 & $\mathrm{Ca}$ & 0.14 \\
\hline $\mathrm{Al}_{2} \mathrm{O}_{3}$ & 10.2 & $\mathrm{Al}^{\mathrm{iv}}$ & 0.58 & $\mathrm{Na}$ & 0.68 \\
\hline $\mathrm{Cr}_{2} \mathrm{O}_{3}$ & 0.02 & & & $\mathrm{~K}$ & 0.06 \\
\hline $\mathrm{FeO}$ & 14.1 & $\mathrm{Al}^{\mathrm{vi}}$ & 1.18 & & \\
\hline $\mathrm{MnO}$ & 0.10 & $\mathrm{Ti}$ & 0.17 & & \\
\hline $\begin{array}{l}\mathrm{MgO} \\
\mathrm{CaO}\end{array}$ & $\begin{array}{l}8.8 \\
0.90\end{array}$ & $\mathrm{Cr}$ & - & $\begin{array}{l}Z \\
X Y\end{array}$ & $\begin{array}{l}2.00 \\
5.90\end{array}$ \\
\hline $\mathrm{Na}_{2} \mathrm{O}$ & 2.4 & $\mathrm{Fe}$ & 1.73 & & \\
\hline $\mathrm{K}_{2} \mathrm{O}$ & 0.34 & Mn & 0.01 & Sum & 7.90 \\
\hline Total & 88.96 & $\mathrm{Mg}$ & 1.93 & & \\
\hline
\end{tabular}

Note: Analysis is the average of 25 spot analyses by

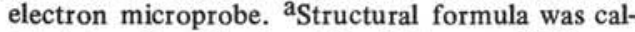
culated on $0=22$ and not $0=24$ because $\mathrm{H}_{2} \mathrm{O}$ cannot be determined by electron microprobe

reason to believe that the basaltic material could not represent only one basaltic source or event.

Oceanic alkalic and nephelinic basalt are almost invariably associated with islands and seamounts (e.g., Engel et al., 1965; Aumento, 1968; Clague, 1974), commonly at island centers that are, in some cases, known to have previously erupted tholeiitic basalt (Hawaii is the classic example). Therefore, it is reasonable to assume that the volcanic source for the Rio Grande Rise breccia was a volcanic island or seamount. Moreover, the presence of sanidine in the breccia indicates highly alkalic, differentiated volcanic material from a volcanic island such as that found on Fernando de Noronha and Trinidade as trachytes and phonolites (Baker, 1973).

At its present site, the breccia is over- and underlain by deep-water pelagic sediments (Figure 2), but the graded bedding and the shallow-water fossil components suggest deposition in one event, possibly by slump from an upslope source. Thick calcareous deposits mantle the slopes of the Rio Grande Rise (McDowell et al., this volume) and any volcanic structure that formed a core for the rise would have been well protected against erosion during subsidence of the rise. This limits the hyaloclastic eruption to an area that was submerged for a relatively short time, such as near-shore, and it is therefore unlikely that the breccia represents pre-Eocene material displaced during Eocene time. Moreover, no fossiliferous material older than Eocene was observed. It should be noted, however, that the absence of volcanic material interspersed with sediments cored from the Rio Grande Rise (Maxwell et al., 1970; Perch-Nielsen et al., this volume) indicate much of the volcanism associated with the rise was probably early in its origin (i.e., early history of South Atlantic rifting).

The sanidine grains, which are compatible with differentiated high-alkali rocks, rather than mafic (basaltic) rocks, were apparently intermixed with the basaltic fragments much the way fossiliferous material was. The source of the sanidine, however, was probably a differentiated portion of the same volcanic structure that provided the basaltic fragments.

The Rio Grande Rise breccia is interpreted as representing an explosive, shallow-water eruption (hyaloclastic) of highly alkalic (possibly nephelinic) basalt. Because hyaloclastites are associated with seamounts (Bonatti, 1967), as is alkalic basaltic material (and the volcanic source for the sanidine), the eruption probably occured on the flank or summit of a seamount, or the flank of a volcano. The hyaloclastite, along with associated fossiliferous material and sanidine ("xenocrysts"), underwent slump to a pelagic environment.

This breccia provides the first quantitative data for the composition of the crystalline basement of the Rio Grande Rise and further indicates that the rise was composed in part of alkalic volcanos during Eocene time. The occurrence of alkali-rich basaltic material at DSDP Site 357, as opposed to ocean-ridge tholeiite, lends some support to the Rio Grande Rise having formed according to the hot-spot theory. That is, the basement material for the rise may represent a semicontinuous chain of volcanic islands generated on the Mid-Atlantic Ridge (Dietz and Holden, 1970; Morgan, 1971). However, the possibility of alkalic volcanic-islands having formed along fracture zones prior to and during Eocene time cannot be completely ruled out.

\section{ACKNOWLEDGMENTS}

We thank J.W. Husler (University of New Mexico) for the wet-chemical analysis, and M.D. Rogers (Union College) for $\mathrm{X}$-ray analysis. Microprobe analyses were made under partial support by the National Aeronautics and Space Administration Grants NGL 32-004-064 and NGL 32-004063 (K. Keil, University of New Mexico, Principal Investigator). We also thank the National Science Foundation for letting us participate in Leg 39 of the Deep Sea Drilling Project.

\section{REFERENCES}

Aumento, F., 1968. The Mid-Atlantic Ridge near $45^{\circ} \mathrm{N}$. II. Basalts from the area of Confederation Peak: Canadian J. Earth Sci. v. 5, p. 1.

Baker, P.E., 1973. Islands of the South Atlantic. In Nairn and Stehli (Eds.), The ocean basins and margins, v.1: New York (Plenum Press), p. 493.

Banks, H., 1972. Iron-rich saponite: Additional data on samples dredged from the mid-Atlantic ridge, $22^{\circ} \mathrm{N}$. Smithson: Contrib. Earth Sci., No. 9, p. 39.

Bonatti, E., 1967. Mechanisms of deep-sea volcanism in the South Pacific. In Abelson, P. (Ed.), Researches in geochemistry, v. 2: New York (John Wiley), p. 453.

Clague, D.A., 1974. Nephelinic lavas dredged from the western Hawaiian ridge (abstr.): Geol. Soc. Am. Abstr. with Prog., v. 6, p. 156.

Dietrich, G., and Ulrich, J., 1968. Atlas fur Ozeanographie: Mannheim (Bibliographisches Institut),

Dietz, R.S. and Holden, J.C., 1970. Reconstruction of Pangaea: Breakup and dispersion of continents, Permian to Recent: J. Geophys. Res., v. 75, p. 4939. 
Engel, A.E.J., Engel, C.G., and Havens, R.G., 1965. Chemical characteristics of oceanic basalts and the upper mantle: Geol. Soc. Am. Bull., v. 76, p. 719.

Fodor, R.V., Keil, K., and Bunch, T.E., 1975. Contributions to the mineral chemistry of Hawaiian rocks IV. Pyroxenes in rocks from Haleakala and West Maui volcanoes, Maui, Hawaii: Contrib. Mineral. Petrol., v. 50, p. 173.

Le Pichon, X. and Hayes, D.E., 1971. Marginal offsets, fracture zones, and the early opening of the South Atlantic: J. Geophys. Res. v. 76, p. 6283.

Leyden, R., Ludwig, W.J., and Ewing, M., 1971. Structure of the continental margin off Punta del Este, Uruguay and Rio de Janeiro, Brazil: Am. Assoc. Petrol. Geol. Bull., v. 55 , p. 2161 .
Maxwell, A.E., Von Herzen, R.P., Hsü, K.J., Andrews, J.E., Saito, T., Percival, S.F., Milow, D., and Boyce, R.E., 1970. Deep-sea drilling in the South Atlantic: Science, v. 168 , p. 1047.

Melson, W.G. and Thompson, G. 1973. Glassy abyssal basalts, Atlantic sea floor near St. Paul's rocks: Petrography and composition of secondary clay minerals: Geol. Soc. Am. Bull., v. 84, p. 703.

Morgan, W.J., 1971. Convection plumes in the lower mantle. Nature v. 230, p. 42.

Thiede, J., in press. The subsidence of aseismic ridges: Evidence from sediments on Rio Grande rise (SW Atlantic Ocean): Am. Assoc. Petrol. Geol. Bull. 